Revista Brasil. Bot., V.31, n.2, p.339-344, abr.-jun. 2008

\title{
Cryptophiale and Cryptophialoidea (Conidial fungi) from Brazil and keys to the genera
}

\section{MARCOS FABIO OLIVEIRA MARQUES ${ }^{1,3,4}$, ALISSON CARDOSO RODRIGUES DA CRUZ1, FABIO FERNANDES BARBOSA ${ }^{1,2}$ and LUÍS FERNANDO PASCHOLATI GUSMÃO ${ }^{1}$}

(received: April 19, 2007; accepted: May 21, 2008)

\begin{abstract}
Cryptophiale and Cryptophialoidea (Conidial fungi) from Brazil and keys to the genera). During a survey of microfungi associated with dead leaves in the State of Bahia, Brazil, four species of Cryptophiale Piroz. and two species of Cryptophialoidea Kuthub. \& Nawawi were found. Cryptophiale guadalcanalensis Matsush. and Cryptophialoidea fasciculata Kuthub. \& Nawawi are new records for the neotropics, while C. ramosa Delg.-Rodr., J. Mena \& Gené is a new record for South America. Descriptions, illustrations and geographical distribution of all the fungi are provided.
\end{abstract}

Key words - anamorphic fungi, biodiversity, Hyphomycetes, leaf litter

RESUMO - (Cryptophiale e Cryptophialoidea (Fungos Conidiais) no Brasil e chave para os gêneros). Durante a investigação de microfungos associados a folhas em decomposição no Estado da Bahia, quatro espécies de Cryptophiale Piroz. e duas de Cryptophialoidea Kuthub. \& Nawawi foram encontradas. Cryptophiale guadalcanalensis Matsush. e Cryptophialoidea fasciculata Kuthub. \& Nawawi constituem novos registros para o Neotrópico e C. ramosa Delg.-Rodr., J. Mena \& Gené é um novo registro para a América do Sul. São apresentadas neste estudo, descrições, comentários, ilustrações e distribuição geográfica.

Pavavras-chave - biodiversidade, fungos anamorfos, Hyphomycetes, serapilheira

\section{Introduction}

The genus Cryptophiale was established by Pirozynski (1968) based on two foliicolous species, $C$. kakombensis Piroz. (type species) and C. udagawae Piroz. \& Ichinoe. The genus has eighteen accepted species and is characterized by the presence of unbranched or dichotomously branched, setiform conidiophores, phialidic conidiogenous cells obscured by a shield of sterile cells located at the middle of setiform conidiophore and falcate to cylindrical, hyaline, 1-10-septate, conidia aggregated in slime mass (Pirozynski, 1968; Farr, 1980; Kuthubutheen 1987; Kuthubutheen \& Sutton 1985; Goh \& Hyde 1996; Mercado-Sierra et al. 1997; Umali et al. 1999; Delgado et al. 2005).

In a study of microfungi associated with palms plants, Hyde et al. (1999) established connections for Cryptophiale kakombensis and C. udagawae with their perithecial teleomorphs in Ascomycetes, Chaetosphaeria

1. Universidade Estadual de Feira de Santana, Dept. de Ciências Biológicas, Laboratório de Micologia, BR116 KM03, 44031-460 Feira de Santana, BA, Brazil.

2. Universidade Federal da Bahia, Instituto de Química, Laboratório de Biotecnologia e Química de Microrganismos, Rua Barão de Geremoabo, s/n, Campus de Ondina, 40170-290 Salvador, BA, Brazil.

3. Universidade do Estado da Bahia, Campus VII, Dept. de Educação, Laboratório de Microbiologia, Rodovia Lomanto Júnior, BR 407 KM 127, 48.970-000 Senhor do Bonfim, BA, Brazil.

4. Corresponding author: mfomarques@yahoo.com.br saltuensis K. D. Hyde, Goh, Joanne E. Taylor \& J. Fröhl. and C. hongkongensis K. D. Hyde, Goh, Joanne E. Taylor \& J. Fröhl., respectively.

Kuthubutheen \& Nawawi (1987) proposed the segregation of Cryptophiale secunda Kuthub. \& B. Sutton in a new genus, Cryptophialoidea Kuthub. \& Nawawi. Five species are clustered in this genus, essentially distinguished by phialides without obscured by a shield of sterile cells and the conidiogenous apparatus located at the middle and disposed on only one side of the setiform conidiophores.

The species of both these genera are found associated with decaying leaves, wood, and roots of several plants in tropical and subtropical regions (Goh \& Hyde 1996; Mercado-Sierra et al. 1997). Only one species, Cryptophiale sphaerospora Umali \& D.Q. Zhou, was collected as parasite on synnemata of Janetia synnematosa Sivan. \& Hsieh (Umali et al.1999). For Brazil, only three species of Cryptophiale have so far been collected, C. minor M.L. Farr (Farr 1980), C. kakombensis (Grandi \& Attili 1996) and C. udagawae (Sutton \& Hodges 1976) and one species of Cryptophialoidea, C. manifesta, (as Cryptophiale manifesta) (Sutton \& Hodges 1976).

During a study of microfungi associated with decaying leaves in Bahia State, some interesting species of these genera have been collected. They are described, illustrated and commented in this paper. A key is proposed to the known species of Cryptophiale and Cryptophialoidea after Goh \& Hyde (1996) and Delgado et al. (2005). 


\section{Material and methods}

Decaying leaves colonized by fungi were collected from various places such as Lençóis, Mucugê, Palmeiras, Rui Barbosa, Salvador and Santa Terezinha in Bahia State, during April 2000 to Nov. 2005. Following the leaf washing technique of Harley \& Waid (1955), fragments of leaves were incubated in moist chambers at room temperature for development of fungal reproductive structures. Isolated fungi were identified from the slides prepared with PVL resin (Trappe \& Schenck 1982). Permanent slides were deposited as herbarium specimens at "Herbário da Universidade Estadual de Feira de Santana" (HUEFS).

\section{Results and discussion}

Cryptophiale guadalcanalensis Matsush. [as 'guadalcanalense'], Microfungi of the Solomon Islands and Papua-New Guinea:15. 1971.

Figura 1

Conidiophores setiform, straight or flexuous, septate, smooth, brown, 177-276 $\times 6-9 \mu \mathrm{m}, 1-5$ dichotomously branched at the apex, fertile from the middle up to branched apex 52.5-68 $\times 11.5-14.5 \mu \mathrm{m}$. Conidiogenous cells enteroblastic, phialidic, obscured by a shield of sterile cells. Conidia solitary, 1-septate, subulate, simple, smooth, produced in slimy masses, hyaline, 15.5-20 $\times 1.2 \mu \mathrm{m}$.

Material examined: BRAZIL. BAHIA: Santa Terezinha, Serra da Jibóia, on dead leaves, 22-III-2005, A.C.R. Cruz s.n. (HUEFS97967).

Known distribution: Japan and Salomon Island (Matsushima 1975), India (Rao \& De Hoog 1986).

The Brazilian specimen has smaller conidiophores and conidia and dichotomously branched conidiophores than the material described by Matsushima (1975). Three species, viz. C. cucullata Kuthub., C. guadalcanalensis and $C$. udagawae, have branched, setiform conidiophores. In $C$. udagawae, the conidiogenous apparatus is restricted to the unbranched part of setiform conidiophore (Pirozynski 1968; Kuthubutheen 1987). Whereas in $C$. cucullata and $C$. guadalcanalensis, the conidiogenous apparatus is extended within the branches. In C. cucullata, the conidiogenous apparatus extended up to the second dichotomy and the conidia are subulate with a distinct flexuous appendix (Kuthubutheen 1987).

Cryptophiale kakombensis Piroz., Can. J. Bot. 46: 1124. 1968.

Figura 2

Conidiophores setiform, simple, straight or flexuous, unbranched, septate, smooth, brown, 228-390 × 7.5-9 $\mu$, fertile from the middle up to sub apex, $81-111 \times 12-21 \mu \mathrm{m}$. Conidiogenous cells enteroblastic, phialidic, obscured by a shield of sterile cells. Conidia solitary, 1-septate, falciform, simple, smooth, produced in slimy masses, hyaline, $21-24 \times 1.5 \mu \mathrm{m}$.

Material examined: BRAZIL. BAHIA: Santa Terezinha, Serra da Jibóia, on decaying leaves, 22-III-2005, A.C.R. Cruz s.n. (HUEFS97968); Lençois, Fazenda Araruna, on decaying leaves, 9-VI-2003, A.C.R. Cruz s.n. (HUEFS56864); Palmeiras, Campo de São João, on decaying leaves, 12-XI-2003, A.C.R. Cruz s.n. (HUEFS56865).

Known distribution: Australia, India (Matsushima 1989), Brazil (Grandi 1999), Cuba (Mercado-Sierra et al. 1997), Equator (Matsushima 1993), Federative States of the Micronesia, Taiwan (Matsushima 1985), Ivory Coast, United States of America (Farr et al. 2007), Malaysia (Kuthubutheen \& Sutton 1985), Mexico (Heredia-Abarca 1994), Seychelles (Hyde et al. 1999), Tanzania (Pirozynski 1968) and Venezuela (Castañeda-Ruiz et al. 2003).

This is a very common species of the genus occurring intermixed with C. udagawae on leaf litter and reported first from Ivory Coast by Rambelli et al. (2004). In Brazil, this species was first recorded from Juréia-Itatins Reserve, São Paulo State by Grandi \& Attili (1996). Subsequently, it was found in the Bahia state, from Chapada Diamantina (Gusmão et al. 2005) and Pará state (Gutierrez A.H. unpublished data).

Cryptophiale minor M.L. Farr, Mycotaxon 11: 177. 1980.

Description and illustration of the species can be found in Farr (1980).

Conidiophores setiform, $120-200 \times 6-8 \mu \mathrm{m}$, fertile region 30-50 $\mu \mathrm{m}$ long. Conidia 1-septate, 12-14(16) $\times 1.2 \mu \mathrm{m}$.

Know distribution: Brazil (Farr 1980), Cuba (unpublished data).

This fungus was isolated from large zonate spots from dead leaves of Astrocaryum G. Mey (Arecaceae) along the Rio Negro, Amazonas State. According to Farr (1980), the species appears to be close to C. iriomoteana Matsush., but the conidia of the latter are consistently subulate and strongly curved, sometimes even hook-like at the apex. The variability of conidial shape in C. minor is an unusual feature since the conidial shape appears to be uniform in other species of the genus Cryptophiale.

Cryptophiale udagawae Piroz. \& Ichinoe, Can. J. Bot. 46: 1126. 1968.

Figura 3

Conidiophores setiform, straight or flexuous, septate, smooth, brown, with 3-4 branches at the apex, 97.5-150 


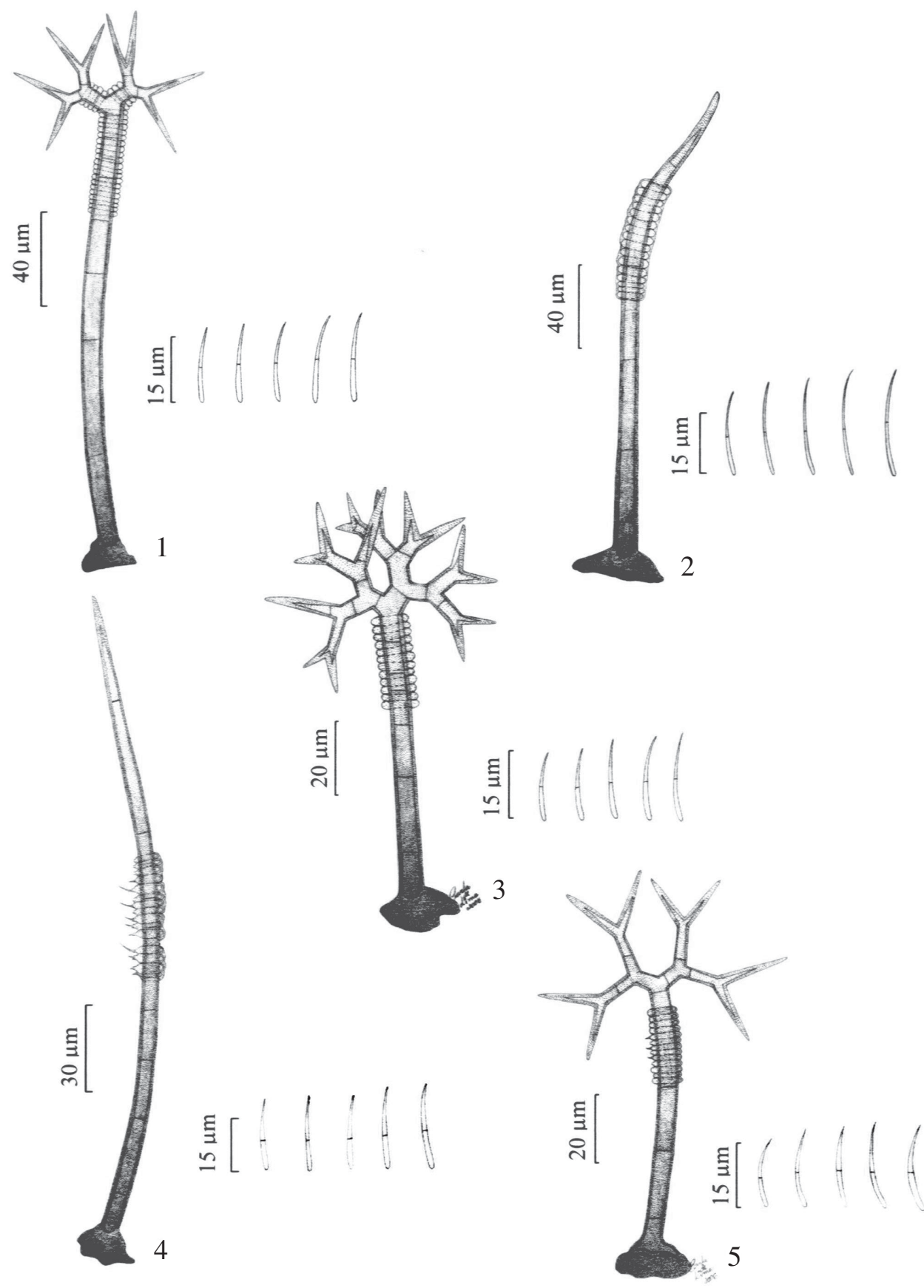

Figures 1-5. 1. Cryptophiale guadacanalensis, conidiophores setiform, branched, fertile region with conidiogenous cells up to first dichotomy branches, and conidia. 2. Cryptophiale kakombensis, conidiophores setiform, fertile region with conidiogenous cells, and conidia. 3. Cryptophiale udagawae, conidiophores setiform, branched, fertile region with conidiogenous cells up to dichotomy branches, and conidia. 4. Cryptophialoidea fasciculata, conidiophores setiform, bundles of conidiogenous cells, and conidia. 5. Cryptophialoidea ramosa, conidiophores setiform, branched, bundle of conidiogenous cells, and conidia.

$\times 4.5-9 \mu \mathrm{m}$, fertile from middle up to first dichotomy branch at the apex 22.5-51 $\times 9-13.5 \mu \mathrm{m}$. Conidiogenous cells enteroblastic, phialidic, obscured by a shield of sterile cells. Conidia solitary, 1-septate, falcate, simple, smooth, hyaline, produced in slimy masses, 15.5-20 $\times 1.2 \mu \mathrm{m}$.
Material examined: BRAZIL. BAHIA: Santa Terezinha, Serra da Jibóia, on decaying leaves, 24-X-2005, M.F.O. Marques s.n. (HUEFS98034).

Known distribution: Australia (Matsushima 1989), Brazil (Grandi 1999), China, Japan, Ivory Coast, New 
Guinea, New Zealand, United States of America (Farr et al. 2007), Cuba (Mercado-Sierra et al. 1997), Equator (Matsushima 1993), Malaysia (Kuthubutheen \& Sutton 1985), Mexico (Heredia-Abarca 1994), Taiwan (Matsushima 1980) and Venezuela (Castañeda-Ruiz et al. 2003).

The conidiophores, fertile zone and conidia from the present collection were smaller than described by Pirozynski (1968) and Kuthubutheen \& Sutton (1985). This species presents variable number of branches in the conidiophore, i.e. from 1 to 3 by Pirozynski (1968) and Kuthubutheen \& Sutton (1985), 3 by Matsushima (1971) and 5 to 8 by Mercado-Sierra et al. (1997). In Brazil, it was collected in the States of Espírito Santo (Sutton \& Hodges 1976) and São Paulo (Grandi \& Attili 1996). This is the first record of the fungus from Bahia state.

Cryptophialoidea fasciculata Kuthub. \& Nawawi, Mycol. Res. 98: 686. 1994.

Figura 4

Conidiophores setiform, simple, straight or flexuous, unbranched, septate, smooth, brown at the base, dark brown at apex, 220-262 ×5-6 $\mu \mathrm{m}$, fertile from the middle up to sub apex, 27-70 $\mu$ m. Conidiogenous cells enteroblastic, monophialidic, discrete, determinate, lageniform, 11.5-15 $\times 2-3.5 \mu \mathrm{m}$, with inconspicuous collarettes. Conidia solitary, 1 -septate, falcate, hyaline, simple, smooth, produced in slimy masses, 20-24.5 × 1.5-2 $\mu \mathrm{m}$.

Material examined: BRAZIL, BAHIA: Mucugê, on dead leaves of Chamaecrista cytizoides var. blanchet (Benth.) H. S. Irwin \& R. C. Barneby (Caesalpiniaceae), 23-I-2000, L.F.P. Gusmão s.n. (HUEFS42710); Rui Barbosa, Serra do Orobó, on dead leaves of Gaylussacia brasiliensis Meissn. (Vacciniaceae), 16-IV-2000, L.F.P. Gusmão s.n. (HUEFS42779); Lençóis, on dead leaves of Clusia nemorosa G.F.W. Mey (Guttiferae), 25-IV-2000, L.F.P. Gusmão s.n. (HUEFS56615); Salvador, APA das Lagoas e Dunas do Abaeté, on dead leaves of Manilkara salzmanii (DC.) H.J. Lam. (Sapotaceae), 24-VIII-2005, F.F. Barbosa s.n. (HUEFS98055).
Known distribution: Malaysia (Kuthubutheen \& Nawawi 1994).

The conidia are shorter in the material studied compared to the original description (Kuthubutheen \& Nawawi, 1994). This is the second record of C. fasciculata.

Cryptophialoidea ramosa Delgado, J. Mena \& Gené, Fung. Divers. 20: 31. 2005.

\section{Figura 5}

Conidiophores setiform, straight or flexuous, septate, smooth, brown, 115.5-141 × 6-7.5 $\mu \mathrm{m}$, dichotomously branched 2-3 times at the apex, fertile from the middle to the first dichotomy branch (not included it), 24-39 $\times 12-16.5 \mu \mathrm{m}$. Conidiogenous cells enteroblastic, monophialidic, discrete, determinate, lageniform, with inconspicuous collarettes. Conidia solitary, 1-septate, falcate, slightly curved, simple, smooth, produced in slimy masses, hyaline, 16-20.5 × 1-1.2 $\mu$ m.

Materials examined: BRAZIL, BAHIA: Santa Terezinha, Serra da Jibóia, on decaying leaves, 09-XI-2005, M.F.O. Marques s.n. (HUEFS98035); Salvador, APA das Lagoas e Dunas do Abaeté, on dead leaves of Anacardium occidentalis L. (Anacardiaceae), 29-VIII-2005, F.F. Barbosa s.n., (HUEFS98056).

Known distribution: Cuba (Delgado et al. 2005).

The specimens collected are compatible with the original description (Delgado et al. 2005). These are distinguished from the original description, by the presence of dichotomous branches at the apex of conidiophores and slightly smaller conidial dimensions. The species with dichotomous branches in the conidiophores such as Cryptophiale udagawae, C. guadalcanalensis and $C$. cucullata could be confused with Cryptophialoidea ramosa, although they are clearly distinguishable when observed through the conidiogenous apparatus, phialides without collarettes and obscured by a shield of sterile cells on each side of the conidiophores (Delgado et al. 2005). The Brazilian collection constitutes the second record of the species.

Key to species of Cryptophiale and Cryptophialoidea [After Goh \& Hyde (1996) and Delgado et al. (2005)].

1. Fertile region of conidiophore lacking shield of sterile cell or rudimentary on the

base of phialide bundles

2. Setiform conidiophores dichotomously branched

Cryptophialoidea ramosa

2. Setiform conidiophores unbranched

3. Conidiogenous cells predominant polyphialidic Cryptophialoidea manifesta

3. Conidiogenous cells monophialidic

4. Conidia falcate

4. Conidia uncinate Cryptophialoidea uncispora

5. Phialides arranged in discrete bundles Cryptophialoidea fasciculata 
5. Phialides not arranged in bundles

Cryptophialoidea secunda

1. Fertile region of conidiophore with shield of sterile cell covering the phialides

6. Conidiophore apex branched

7. Fertile region of conidiophore at middle

Cryptophiale udagawae

7. Fertile region of conidiophore apical or subapical

8. Conidial apex appendiculate Cryptophiale cucullata

8. Conidial apex not appendiculate Cryptophiale guadalcanalensis

6. Conidiophore apex unbranched

9. Conidia 3-10 septate

10. Conidial apex appendiculate

Cryptophiale enormis

10. Conidial apex not appendiculate

11. Conidia 72-95 $\times 2.5-3 \mu \mathrm{m}$

Cryptophiale pandanicola

11. Conidia 30-62 $\times 2.5-4 \mu \mathrm{m}$

Cryptophiale multiseptata

9. Conidia $0-1$ septate

12. Conidia lacking septum

13. Conidiophore with setiform lateral branches

14. Setiform branches distinctly verruculose

Cryptophiale verrucosa

14. Setiform branches not verruculose Cryptophiale apicalis

13. Conidiophore lacking setiform lateral branches

15. Conidia spherical to subspherical

Cryptophiale sphaerospora

15. Conidia with others forms

16. Conidia 20-28 $\times 4-4.5 \mu \mathrm{m}$, apex appendiculate

Cryptophiale caudata

16. Conidia 5.5-12 $\times 0.5 \mu \mathrm{m}$, apex not appendiculate

Cryptophiale pusilla

12. Conidia with a single median septum

17. Length of conidiophores never more than $350 \mu \mathrm{m}$

18. Conidia narrowly obclavate, apex distinctly uncinate

Cryptophiale iriomoteanum

18. Conidia falcate or fusiform, apex not uncinate

19. Fertile region of conidiophore apical, up to $110 \mu \mathrm{m}$;

conidia 22-30 $\mu \mathrm{m}$ long

Cryptophiale kakombensis

19. Fertile region of conidiophore median, 30-50 $\mu \mathrm{m}$ long;

conidia $12-14 \mu \mathrm{m}$ long

Cryptophiale minor

17. Length of conidiophores up to $410 \mu \mathrm{m}$ or longer

20. Fertile region of conidiophore basal

Cryptophiale insularis

20. Fertile region of conidiophore apical or subapical

21. Fertile region of conidiophore subapical, conidia cylindrical or obclavate

Cryptophiale orthospora

21. Fertile region of conidiophore apical, conidia fusiform or subulate

22. Conidia 23-27 $\mu \mathrm{m}$ long, apex appendiculate.

22. Conidia 9.5-18 $\mu \mathrm{m}$ long, apex not apendiculate

Cryptophiale aristata

Cryptophiale novae-caledoniae

Acknowledgement - We are grateful to Prof. D.J. Bhat (Department of Botany, Goa University, India) for kindly reviewing the manuscript. Marcos Fabio Oliveira Marques and Alisson Cardoso Rodrigues da Cruz wish to acknowledge CAPES (Coordenação de Aperfeiçoamento de Pessoal de Nível Superior) and CNPq (Conselho Nacional de Desenvolvimento Científico e Tecnológico), respectively, for providing grants. The authors are grateful to "Programa Flora da Bahia" for facilities during expeditions in the "Campo rupestre" vegetation and CNPq (Proc. 471619/04-3) for the financial support to Serra da Jibóia project.

\section{References}

CASTAÑEDA-RUIZ, R.F., ITURRIAGA, T., MINTER, D.W., SAIKAWA, M., VIDAL, G. \& VELÁZQUEZNOA, S. 2003. Microfungi from Venezuela, a new species of Brachydesmiella, a new combination, and new records. Mycotaxon 85:211-229.

DELGADO, G., MENA-PORTALES, J., GENÉ, J. \& GUARRO, J. 2005. New species of Cryptophialoidea and Hughesinia (Hyphomycetes, anamorphic fungi) from Cuba. Fungal Diversity 20:31-38. 
FARR, M.L. 1980. A new species of Cryptophiale from Amazonas. Mycotaxon 11:177-181.

FARR, D.F., ROSSMAN, AY., PALM, M.E. \& MCCRAY, E.B. 2007. Fungal Databases, systematic Botany \& Mycology Laboratory, ARS, USDA. http://nt.ars-grin. gov/fungaldatabases/ (acesso em 14/01/2007)

GOH, T.K. \& HYDE, K.D. 1996. Cryptophiale multiseptata, sp. nov. from submerged wood in Australia, and keys to the genus. Mycological Research 100:999-1104.

GRANDI, R.A.P. \& ATTILI, D.S. 1996. Hyphomycetes on Alchornea triplinervia (Spreng.) Müell. Arg. leaf litter from the Ecological Reserve Juréia-Itatins, State of São Paulo, Brazil. Mycotaxon 60:373-386.

GRANDI, R.A.P. 1999. Hifomicetos decompositores do folhedo de Euterpe edulis Mart. Hoehnea 26:87-101.

GUSMÃO, L.F.P., GÓES-NETO, A. \& CRUZ, A.C.R. 2005. Fungos. In Biodiversidade e Conservação da Chapada Diamantina (F.A. Juncá, L. Funch \& W. Rocha orgs.) Brasília, Ministério do Meio Ambiente. p.225-240.

HARLEY, J.L. \& WAID, J.S. 1955. A method of studing active mycelia on living roots and other surfaces in the soil. Transactions of the British Mycological Society 38:104-118.

HEREDIA-ABARCA, G. 1994. Hifomicetes dematiaceos em Bosque mesofilo de montana. Registros nuevos para México. Acta Botánica Mexicana 27:15-32.

HYDE, K.D., GOH, T.K., TAYLOR, J.E. \& FROHLICH, J. 1999. Byssosphaeria, Chaetosphaeria, Niesslia and Ornatispora gen. nov., from palms. Mycological Research 103:1423-1439.

KUTHUBUTHEEN, A.J. 1987. Another new species of Cryptophiale from Malaysia. Transactions of the British Mycological Society 89:274-278.

KUTHUBUTHEEN, A.J. \& NAWAWI, A. 1987. Cryptophialoidea gen. nov. on decaying leaves from Malaysia. Transactions of the British Mycological Society 89:581-583.

KUTHUBUTHEEN, A.J. \& NAWAWI, A. 1994. Cryptophialoidea fasciculata sp. nov. and C. manifesta comb. nov. from Malaysia. Mycological Research 98:686-688.
KUTHUBUtheEN, A.J. \& SUTTON, B.C. 1985. Cryptophiale from Malaysia. Transactions of the British Mycological Society 84:303-306.

MATSUSHIMA, T. 1971. Microfungi of the Solomon Islands and Papua-New Guinea. Published by the author, Kobe.

MATSUSHIMA, T. 1975. Icones Microfungorum a Matsushima Lectorum. Published by the author, Kobe.

MATSUSHIMA, T. 1980. Matsushima Mycological Memoirs n. 1. Published by the author, Kobe.

MATSUSHIMA, T. 1985. Matsushima Mycological Memoirs n. 4. Published by the author, Kobe.

MATSUSHIMA, T. 1989. Matsushima Mycological Memoirs n. 6. Published by the author, Kobe.

MATSUSHIMA, T. 1993. Matsushima Mycological Memoirs n. 7. Published by the author, Kobe.

MERCADO-SIERRA, A., HOLUBOVÁ-JECHOVÁ, V. \& MENA-PORTALES, J. 1997. Hifomicetos demaciáceos de Cuba. Enteroblásticos. Museo Regionale di Scienze Naturali, Monografie XIII. Torino, Italia.

PIROZYNSKI, K.A. 1968. Cryptophiale, a new genus of Hyphomycetes. Canadian Journal of Botany 46:11231127.

RAMBELLI, A., MULAS, B.E \& PASQUALETTI, M. 2004. Comparative studies on microfungi in tropical ecosystems in Ivory Coast forest litter: behavior on different substrata. Mycological Research. 108:325336.

RAO, V. \& DE HOOG, G.S. 1986. New or critical Hyphomycetes from India. Studies in Mycology 28:1-84

SUTTON, B.C. \& HODGES, C.S. 1976. Eucalyptus microfungi: some setose Hyphomycetes with phialides. Nova Hedwigia 27:343-352.

TRAPE, J.M. \& SCHENCK, N.C. 1982. Taxonomy of fungi forming endomycorrhizae.. In Methods and Principles of mycorrizal research (N.C. Schenck ed.). The American Phytopathological Society. St. Paul, p.1-9.

UMALI, T.E., ZHOU, D., GOH, T.K. \& HYDE, K.D. 1999. Cryptophiale sphaerospora sp. nov. occurring on Janetia synnematosa. Mycoscience 40:189-192. 